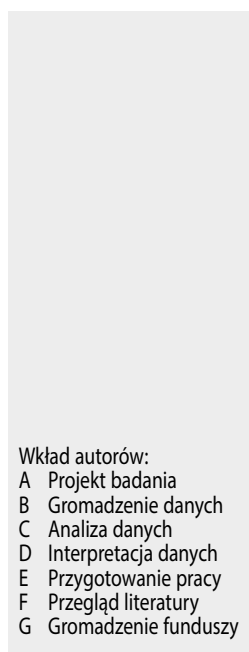

\title{
Słuch fonemowy uczniów I klasy integracyjnej rozpoczynających naukę czytania i pisania
}

\section{Phonemic hearing of students of the first integration class beginning their education in reading and writing}

\author{
Julita Sobańska1ABCDEF, Katarzyna Studzińska-Grzegorczyk ${ }^{2 B C D}$ \\ ${ }^{1}$ Podkarpackie Centrum Słuchu i Mowy „Medincus”, Rzeszów \\ ${ }^{2}$ Publiczna Szkoła Podstawowa z Oddziałami Mistrzostwa Sportowego nr 2 \\ im. Jana Pawła II w Stalowej Woli
}

\begin{abstract}
Streszczenie
Wstęp: Słuch fonemowy, jako jeden z rodzajów słuchu mownego, jest zdolnością odbioru dźwięków mowy dotyczącą ich struktury fonemowej w oparciu o czynności recepcji, rozróżniania, różnicowania i pamięci słuchowej. Przyjęte w niniejszej pracy rozumienie terminu „słuch fonemowy” odnosi się do systemu fonologicznego w jego aspekcie segmentalnym. Prawidłowo wykształcony słuch fonemowy pozwala dziecku właściwie dekodować znaczenie wyrazów, różnicować sylaby i głoski, co na etapie edukacji wczesnoszkolnej ma zasadnicze znaczenie dla rozwoju mowy i komunikacji, czytania oraz pisania. Zaprezentowane w artykule wyniki dotyczą badanej grupy 7-latków i stanowią przyczynek do planowanych analiz słuchu fonemowego u dzieci z klas pierwszych w kontekście nauki czytania i pisania.

Cel: Celem pracy było zbadanie słuchu fonemowego uczniów z integracyjnej I klasy szkoły podstawowej rozpoczynających naukę czytania i pisania oraz analiza trudności edukacyjnych dzieci, u których zdiagnozowano zaburzenia identyfikowania dystynktywnych cech głosek.

Materiał i metoda: Grupa badawcza składała się z 20 uczniów w wieku 7 lat uczęszczających do I klasy o profilu integracyjnym. W tej klasie zdiagnozowano dwoje uczniów z dyslalią wieloraką i troje z afazją motoryczną. Grupę kontrolną stanowiło 20 uczniów z równoległej klasy bez profilu integracyjnego. Badania wykonano wystandaryzowanym narzędziem autorstwa J. Gruby: Test do badania stuchu fonemowego (Gliwice, 2012).

Wyniki: Diagnozę przeprowadzono pod koniec I półrocza szkolnego. Trudności w słuchowym różnicowaniu głosek z opozycji fonologicznych, różniących się: miejscem artykulacji, dwiema cechami dystynktywnymi, sposobem artykulacji i dźwięcznością, odnotowano u 8 uczniów. Zaburzenia słuchu fonemowego stanowiły część składową problemów w nabywaniu systemu językowego u 3 dzieci z afazją motoryczną, 2 uczniów z dyslalią wieloraką, ale również 3 pierwszoklasistów, u których nie zdiagnozowano wad wymowy czy zaburzeń mowy. W grupie kontrolnej dwoje dzieci nie różnicowało poprawnie fonemów różniących się dwiema cechami dystynktywnymi i sposobem artykulacji.

Wnioski: Przeprowadzone badania stanowią element oceny gotowości szkolnej dzieci rozpoczynających edukację. Zaburzenia słuchu fonemowego badanych uczniów są jedną z przyczyn utrzymujących się wad wymowy, trudności w czytaniu metodą analityczną i pisaniu ze słuchu. Wyniki wskazują na potrzebę kontynuacji badań przesiewowych słuchu fonemowego w klasach pierwszych. Zdiagnozowanie problemów w słuchowym różnicowaniu dystynktywnych cech głosek przyczyniło się do wprowadzenia programu terapeutycznego w szkole. Słowa kluczowe: słuch fonemowy • zaburzenia słuchu fonemowego • czytanie i pisanie a słuch fonemowy
\end{abstract}

\section{Abstract}

Introduction: Phonemic hearing, as one of the types of speech-based hearing, is the ability to receive speech sounds about their phonemic structure based on reception, discrimination, differentiation and auditory memory. The understanding of the term „phonemic hearing" adopted in this work refers to the phonological system in its segmental aspect. A properly educated phonemic hearing allows the child to properly decode the meaning of words, to differentiate syllables and voices, which at the early childhood education

Adres autora: Julita Sobańska, Podkarpackie Centrum Słuchu i Mowy „Medincus”, 35-303 Rzeszów, al. Niepodległości 3, j.sobanska@csim.pl 
stage is essential for the development of speech and communication, reading and writing. The results presented in the article refer to the group of 7-year-olds surveyed and constitute a contribution to planned phonemic hearing analyzes in children from the first grades in the context of reading and writing.

Aim: The aim of the study was to examine the phonemic hearing of students from the first class of primary school starting to learn to read and write, and to analyze the educational difficulties of children diagnosed with distorted speech features.

Material and method: The research group consisted of 20 students at the age of 7 attending the 1 st class with an integrational profile. In this class, two students with multiple dyslalia and three with motor aphasia were diagnosed. The control group consisted of 20 students from a parallel class without an integration profile. The research was carried out with a standardized tool by J. Gruba: Test for phonemic hearing (Gliwice, 2012).

Results: The diagnosis was made at the end of the first half-year of school. Difficulties in the auditory differentiation of sounds from phonological oppositions, differing in the place of articulation, two distinctive features, manner of articulation and voicing, were noted in 8 students. Phonemic hearing disorders constituted a part of problems in the acquisition of the language system in 3 children with motor aphasia, 2 students with multiple dyslalia, but also 3 first-grade students who were not diagnosed with speech impediments or speech disorders. In the control group, the two children did not differentiate correctly the phonemes differing in the two distinctive features and the way of articulation.

Conclusions: The conducted research is an element of assessment of school readiness of children starting education. Phonemic hearing disorders of the studied students are one of the causes of persisting speech defects, difficulties in reading by analytical method and writing from hearing. The results indicate the need to continue screening tests of phonemic hearing in first grades. Diagnosing problems in the auditory differentiation of the distinctive features of sounds contributed to the introduction of a therapeutic program at school.

Key words: phonemic hearing • phonemic hearing disorders • reading and writing and phonemic hearing

\section{Wstęp}

W literaturze logopedycznej oraz językoznawczej do tej pory nie ma spójnego stanowiska w kwestii różnicowania i identyfikowania dźwięków mowy. Badacze tego zagadnienia piszą o słuchu fonematycznym, fonemowym, fonologicznym, fonetycznym i mownym. Stosowanie tak wielu pojęć niesie za sobą zarówno rozmaite interpretacje tego samego problemu, jak i zróżnicowane postępowanie diagnostyczno-terapeutyczne.

Z badań zapoczątkowanych przez A. Łurię wynika, że słuch fonematyczny może być rozumiany jako zdolność słuchowego różnicowania fonemów oraz umiejętność dokonywania analizy i syntezy dźwiękowej [1]. Wyróżnione przez autora artkulemy stanowią nawiązanie do pojęcia kinemy, czyli motorycznego wyobrażenia (modelu) głoski wprowadzonego przez polskiego językoznawcę Jana Baudoiuna de Courtenay [1]. Rozróżnienie między akustycznym modelem głoski (czyli fonemem) a jej motorycznym schematem (kinemą) ma fundamentalne znaczenie nie tylko w patologii mowy, lecz także w nauczaniu języków obcych [1].

Termin „słuch fonematyczny” pojawił się na gruncie rodzimej logopedii w 1975 roku. J. Kania w Szkicach logopedycznych zdefiniował to pojęcie jako umiejętność percypowania (wyodrębniania i identyfikowania) elementów fonologicznie relewantnych (istotnych), pomijania zaś cech dla procesu porozumiewania się redundantnych (nieistotnych) [2].

W latach 80. nową definicję słuchu fonematycznego wprowadziła I. Styczek, podając, że jest to umiejętność rozróżniania najmniejszych elementów składowych wyrazów, czyli fonemów (np. /a/ od /o/), a także utożsamiania różnych sposobów wymawiania danej głoski [3].

Z kolei w połowie lat 90. B. Rocławski wprowadził terminy: „słuch fonemowy” i „słuch fonetyczny” [4]. Według badacza „słuch fonemowy” to taki zespół czynników psychicznych lub zdolność mózgu do kwalifikowania każdej głoski, w wyróżnianiu której jest zaangażowany słuch fonetyczny, do określonych, fonologicznie zdeterminowanych klas głosek.

Zdaniem Z.M. Kurkowskiego rozróżnianie i wyodrębnianie dźwięków mowy to rozpoznanie co najmniej dwóch wrażeń (odmiennych fonologicznie i fonetycznie) jako różnych [5]. Funkcję tę określił mianem „słuch mowny”, w ramach którego wyodrębnił:

- słuch fonemowy - odróżnianie/utożsamianie dwóch wypowiedzi różnych/takich samych fonologicznie,

- słuch fonetyczny - odróżnianie różnych głosek stanowiących tę samą klasę głosek (fonem),

- słuch prozodyczny - różnicowanie prozodycznych elementów wypowiedzi (akcent, intonacja, tembr głosu),

- analizę i syntezę sylabową/głoskową - umiejętność świadomego wyróżniania sylab/głosek w wypowiedzi z zachowaniem ich kolejności i łączenie sylab/głosek w całość brzmieniową [5].

Logopedyczną i psychologiczną perspektywę omawianego zagadnienia zaproponowała A. Domagała wraz z U. Mirecką. Badaczki odwołały się do koncepcji funkcji słuchowych w ujęciu M. Zalewskiej nawiązującej do teorii percepcji J. Konorskiego i zdefiniowały słuch fonemowy jako jeden z elementów słuchu mownego, czyli zdolności odbioru dźwięków mowy, dla której istotne są: recepcja (dostrzeganie dźwięku), rozróżnianie (rozpoznawanie dwóch wrażeń dźwiękowych jako różnych), różnicowanie (utożsamianie elementów fonetycznych i fonologicznych jako różnych bądź takich samych) i pamięć (przywoływanie wzorców słuchowych) [6]. Słuch mowny spełnia dwojaką rolę w procesie komunikowania się. Po pierwsze, jest zdolnością ukierunkowaną na nabywanie kompetencji fonologicznej (obok kompetencji składniowej i morfologicznej - jeden z rodzajów kompetencji językowej) [7]. Po drugie, umożliwia odbiór różnorodnych informacji istotnych dla porozumiewania się. $\mathrm{Z}$ pierwszą funkcją słuchu mownego wiążą się dwa jego rodzaje: 
- słuch fonemowy (odnoszący się do systemu fonologicznego w jego wymiarze segmentalnym),

- fonologiczny słuch prozodyczny (odnoszący się do konwencjonalnych cech struktury jednostek suprasegmentalnych języka polskiego: akcent, intonacja, melodia, rytm).

Natomiast drugą funkcję słuchu mownego realizują:

- fonetyczny słuch segmentalny (pozwalający na dostrzeganie różnic między głoskami będącymi realizacją tego samego fonemu),

- fonetyczny słuch prozodyczny (odnoszący się do charakterystyki suprasegmentalnej ciągu fonicznego w wymiarze różnic osobniczych, np. zależnych od emocji) $[6]$.

Według autorek jednego $\mathrm{z}$ dostępnych na rynku wydawniczym testów do badania słuchu fonematycznego - E. Szeląg i A. Szymaszek - słuch fonematyczny zabezpiecza wyodrębnianie $z$ potoku dźwięków mowy tych cech, które odgrywają szczególną rolę w identyfikacji danego fonemu, dzięki czemu konkretny wyraz można odróżnić od innych wyrazów o odmiennym znaczeniu [8]. W literaturze przedmiotu istotny wpływ na liczbę definicji słuchu fonemowego ma odniesienie badaczy do nurtu szkoły fonologicznej (Praskiej Szkoły Strukturalnej lub angielskiej tradycji fonologicznej) determinującej pojmowanie fonemu, a także zakres rozważań wokół problematyki słuchu fonemowego (językoznawczych, logopedycznych, pedagogicznych i psychologicznych). Wartka dyskusja tak wielu środowisk i prowadzenie badań w praktyce logopedycznej przyczynia się do tworzenia nowych narzędzi diagnostycznych oraz wyznaczania etapów prawidłowego bądź nieprawidłowego rozwoju słuchu fonemowego. Kształcenie zdolności słuchowego różnicowania fonemów, analizy i syntezy głoskowej/ sylabowej, a także wrażliwości na prozodyczne cechy mowy są warunkiem sprawności komunikacyjnych oraz podstawą do nauki czytania i pisania.

Początek rozwoju funkcji różnicowania dźwięków mowy przypada na okres gaworzenia. Reakcją dziecka na odbiór dźwięków jest ich artykułowanie: tworzą się asocjacje słuchowo-kinestetyczno-ruchowo-wzrokowe [6]. By 6-miesięczne niemowlę nauczyło się nadawać znaczenie produkowanym przez siebie sylabom, potrzebuje informacji zwrotnej od rodziców, czyli podtrzymania przez nich komunikacji nacechowanej emocjonalnie. W doskonaleniu sprawności percepcyjnej olbrzymie znaczenie przypisuje się tzw. mowie matczynej, która ma „charakterystyczną strukturę prozodyczną, cechuje się wysokim tonem głosu, przesadnym zarysowaniem konturów intonacyjnych, a oprócz tego jest uproszczona syntaktycznie i semantycznie" [6]. Tempo w budowaniu poprawnych wzorców fonetycznych i fonologicznych oraz ich jakość zależą od wartości i liczebności przetwarzanego słuchowo materiału. Na tym etapie rozpoczyna się rozwój specyficznych reakcji w odpowiedzi na rozróżniane kontrasty fonetyczno-fonologiczne języka ojczystego.

Przełom pierwszego i drugiego roku życia jest początkiem wiązania dźwięców mowy $\mathrm{z}$ desygnatami. W umyśle dziecka powstają złożone skojarzenia, a pamięć dźwięków
- polegająca na przywołaniu ich wyobrażeń - daje podstawę pełnienia przez dźwięki mowy funkcji oznaczania [9]. W tym czasie i na kolejnych etapach rozwoju mowy korekta ze strony otoczenia, odnosząca się do prawidłowej realizacji głoski, sylaby czy wyrazu, uświadamia dziecku różnice fonetyczno-fonologiczne. A. Domagała i U. Mirecka podają, że linia rozwojowa słuchu fonemowego przebiega w kierunku od ogólnych wzorców słuchowych do wzorców o charakterze strukturalnym. Końcowym efektem tego procesu jest odkrycie istnienia fonemu (elementarnej jednostki struktury fonologicznej wraz z zespołem przysługujących jej cech dystynktywnych), co stanowi pierwszy krok w budowaniu świadomości fonemowej, która intensywnie rozwija się podczas nauki czytania i pisania, zwłaszcza przy dominacji strategii analitycznych opartych na relacji: litera - głoska - fonem [10].

Podjęte przez I. Liberman i wsp. [11] badania dotyczące świadomości różnicowania fonemów wykazały, że tylko 30\% dzieci w wieku 5-6 lat prawidłowo powtarzało słowo, wystukując jednocześnie liczbę fonemów. Natomiast w grupie 7- i 8-latków odnotowano 95\% poprawnych odpowiedzi. Wyniki świadczą o tym, że w okresie rozwoju mowy dzieci nie są świadome istnienia fonemów [11]. Dopiero etap nauki czytania i pisania odkrywa przed nimi nowe, jakże trudne, jednostki systemu językowego. Potwierdziły to również polskie badania G. Krasowicz-Kupis, z których wynika, że znaczny wpływ na osiągnięcia uczniów w procesie nauki czytania i pisania ma nie tylko zakończony rozwój mowy, lecz także umiejętności o charakterze metajęzykowym: analiza i synteza głoskowa, usuwanie sylab i głosek, rozpoznawanie i tworzenie aliteracji oraz świadomość rymów [12].

Słuch fonemowy odgrywa istotną rolę w rozwoju mowy - pozwala na odróżnianie wypowiedzi różnych i utożsamianie takich samych, a także jest warunkiem rozwoju percepcji fonemowej słów w zakresie ich analizy i syntezy [13]. Z badań słuchu fonemowego wynika, że percepcja fonemów wyprzedza ich realizację [14]. Dzieci niekiedy doskonale odróżniają np. $r$ i $l \mathrm{w}$ na płaszczyźnie odbioru, natomiast brak im kompetencji wykonawczych [15]. Należy jednak zaakcentować, że nieuzasadnione jest zawężanie kwestii percepcji mowy wyłącznie do problematyki różnicowania dźwięków mowy oraz selektywnego wyodrębniania cech fonetycznych i przeciwstawiania jednej opozycji fonetycznej innym. „Czynność percepcji mowy nie sprowadza się wyłącznie do różnicowania jej dźwięków w sylabach i pojedynczych wyrazach oraz do wychwytywania cech dystynktywnych. Poza identyfikacją słyszanych dźwięków nieodłącznym składnikiem tego procesu jest utrzymanie w pamięci kolejnych kilku słów połączonych w związki logiczno-gramatyczne, a następnie powiązanie ich $\mathrm{z}$ określonymi znaczeniami. W złożonym procesie komunikacji nie różnicujemy pojedynczych głosek, sylab czy wyrazów, ale uporządkowane ciągi słowne" [7].

Celem pracy było zbadanie słuchu fonemowego uczniów I klasy o profilu integracyjnym rozpoczynających naukę czytania i pisania oraz analiza trudności edukacyjnych dzieci, u których zdiagnozowano zaburzenia właściwego identyfikowania fonemów. 


\section{Materiał i metoda}

Przed rozpoczęciem badań słuchu fonemowego oceniono u dzieci z grupy badawczej i kontrolnej budowę oraz sprawność motoryczną aparatu mowy. Do diagnozy artykulacji zastosowano test przesiewowy G. Demel załączony do publikacji: Minimum logopedyczne nauczyciela przedszkola [16]. Jest to zestaw $12 \mathrm{kart} /$ plansz zawierających po 12 kolorowych obrazków i jedną kartę przedstawiającą czynności [16]. Autorka podzieliła karty na trzy typy. Karty pierwszego typu dotyczą poszczególnych grup lub szeregów głosek, samogłosek, samogłosek niezgłoskotwórczych, różnicowania par głosek dźwięcznych i bezdźwięcznych. Typ drugi (na odwrotnych stronach kart), to tzw. uzupełnianki słowno-obrazkowe, odpowiadające poprzednim grupom głosek. Typ trzeci, to zbiór obrazków przedstawiających czynności, co daje możliwość sprawdzenia wymowy wszystkich głosek i umiejętności wypowiadania się zdaniami [17].

Podczas badania zadaniem dziecka było powtórzenie wyrazu, wymawianego przez logopedkę, określającego obrazek. To samo narzędzie można wykorzystać do sprawdzenia zasobu słownictwa, wówczas dziecko samodzielnie nazywa obrazki i czynności oraz uzupełnia zdania.

Grupa badana składała się 7 dziewczynek i 13 chłopców w wieku 7 lat. Piętnaścioro uczniów prawidłowo realizowało pełny inwentarz głosek języka polskiego. Wśród 5 pierwszoklasistów, $\mathrm{w}$ tym 3 chłopców $\mathrm{z}$ afazją motoryczną, odnotowano: deformacje głosek środkowojęzykowych, przedniojęzykowo-zębowych i przedniojęzykowo-dziąsłowych, a także utrzymującą się mowę bezdźwięczną i substytucję głoski $r$. Seplenienie boczne prawostronne zdiagnozowano u jednego chłopca. Zdarza się, że przy niesymetrycznym układzie masy języka brzmienie głosek jest dobre, ale u badanego ucznia trzy szeregi głosek, których wspólną cechą jest dentalizacja, były zniekształcone. Seplenienie międzyzębowe, będące następstwem przerośniętego migdałka gardłowego, odnotowano u 2 dzieci (stan po adenotomii wykonanej na etapie edukacji przedszkolnej). Jedna dziewczynka z tej klasy nie realizowała fonologicznej kategorii dźwięczności z powodu braku koordynacji między pracą fałdów głosowych a pracą nasady. $\mathrm{U}$ tej samej uczennicy brak pełnej pionizacji masy języka był przyczyną utrzymującej się substytucji głoski $r(l)$. Jeden chłopiec nie realizował głosek dziąsłowych (obserwowano silne parcie powietrza na policzki podczas wymawiania głosek $\check{s}, \check{z}, \check{c}$, $\breve{\zeta}$ i zamiast $r$ pojawiała się samogłoska $y$ ) z powodu obniżonego napięcia mięśniowego $\mathrm{w}$ aparacie artykulacyjnym i braku pionizacji języka.

Grupę kontrolną stanowiło 11 dziewczynek i 9 chłopców. U dwójki uczniów odnotowano substytucję głoski $r(i, l)$, a u jednego dziecka deformację $r$ (realizacja gardłowa). Zarówno substytucja, jak i deformacja w tej grupie były spowodowane niepełną pionizacją masy języka.

Różnicowanie opozycji fonologicznych sprawdzono Testem do badania słuchu fonemowego J. Gruby [18]. Narzędzie opiera się na próbach wyrazowych. W teście przyjęto system fonologiczny opracowany przez $\mathrm{B}$. Rocławskiego. Autor ustalił go, badając świadomość fonologiczną dzieci w wieku przedszkolnym, i przyjął, że w języku polskim występuje 36 par fonemów [19]. Na potrzeby badania fonemy zestawiono w pięć grup par opozycyjnych: opozycje samogłoskowe, fonemy różniące się dwiema cechami dystynktywnymi, opozycje różniące się sposobem artykulacji, miejscem artykulacji i dźwięcznością [19]. Dobór paronimów użytych w narzędziu zaprezentowano również w postaci graficznej. Wybrany materiał opozycji fonemowych autorka testu przedstawiła w formie zdań-rymowanek (np.

Tabela 1. Karta badania słuchu fonemowego [J. Gruba, Test do badania stuchu fonemowego, 2012]

Tabel 1. Phoneme hearing card [J. Gruba, Test for hearing phonemes, 2012]

\begin{tabular}{|l|l|l|}
\hline \multicolumn{2}{|c|}{ KARTA BADANIA StUCHU FONEMOWEGO } \\
\hline A. DANE IDENTYFIKUJĄCE DOKUMENT & Miejsce badania & Data badania \\
\hline Nr badania & Imię & Miejsce zamieszkania \\
\hline B. DANE IDENTYFIKUJĄCE BADANEGO & Wiek & \\
\hline Nazwisko & \multicolumn{2}{|l|}{ Czytelny podpis badającego } \\
\hline Data urodzenia & Poziom słuchu fonemowego & \\
\hline C. WYNIK BADANIA &
\end{tabular}

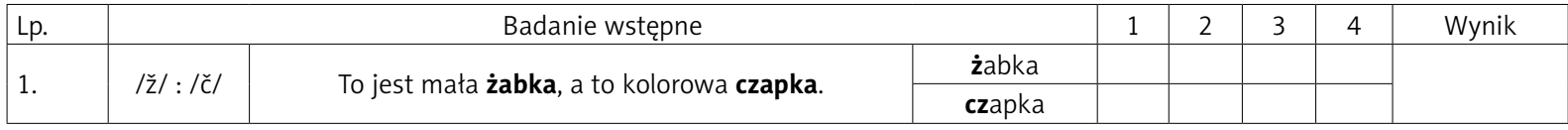

\begin{tabular}{|c|c|c|c|c|c|c|c|c|}
\hline Lp. & \multicolumn{3}{|c|}{ Opozycje samogłoskowe } & 1 & 2 & 3 & 4 & Wynik \\
\hline \multirow{2}{*}{1.} & \multirow{2}{*}{$/ \mathrm{u} / \mathrm{:} / \mathrm{o} /$} & \multirow[t]{2}{*}{ To drzewo to buk, a to samochodu bok. } & buk & & & & & \\
\hline & & & bok & & & & & \\
\hline \multirow{2}{*}{2.} & \multirow{2}{*}{ /i/: /e/ } & \multirow[t]{2}{*}{ To są dwie lipy, to na muchy lepy. } & lipy & & & & & \\
\hline & & & lepy & & & & & \\
\hline \multirow{2}{*}{3.} & \multirow{2}{*}{ /y/: /e/ } & \multirow[t]{2}{*}{ To jest długa tyczka, a to pana teczka. } & tyczka & & & & & \\
\hline & & & teczka & & & & & \\
\hline
\end{tabular}




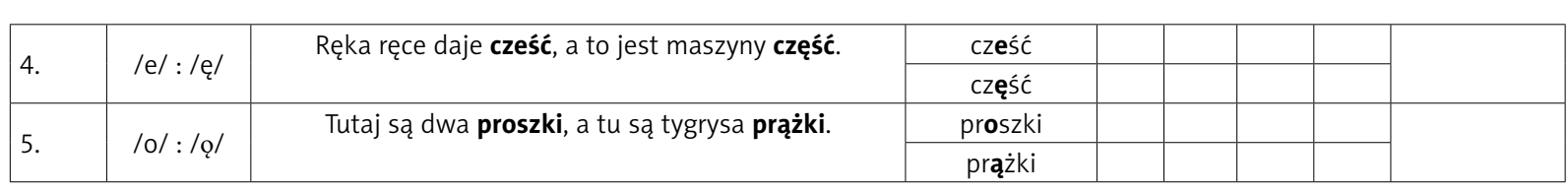

\begin{tabular}{|c|c|c|c|c|c|c|c|c|}
\hline Lp. & \multicolumn{3}{|c|}{ Fonemy różniące się dwiema cechami dystynktywnymi } & 1 & 2 & 3 & 4 & Wynik \\
\hline \multirow{2}{*}{1.} & \multirow{2}{*}{$/ \mathrm{m} /: / \mathrm{b} /$} & \multirow[t]{2}{*}{ To jest z cegły murek, a ten pies to Burek. } & murek & & & & & \\
\hline & & & Burek & & & & & \\
\hline \multirow{2}{*}{2.} & \multirow{2}{*}{$/ \mathrm{n} /: / \mathrm{d} /$} & \multirow[t]{2}{*}{ To żółte banany, ten pan jest badany. } & banany & & & & & \\
\hline & & & badany & & & & & \\
\hline \multirow{2}{*}{3.} & \multirow{2}{*}{$/ \mathrm{i} /: / \mathrm{r} /$} & \multirow[t]{2}{*}{ To jest smocza jama, a to od obrazu rama. } & jama & & & & & \\
\hline & & & rama & & & & & \\
\hline \multirow{2}{*}{4.} & \multirow{2}{*}{ /i/: /l/ } & \multirow[t]{2}{*}{ To jest smocza jama, to zwierzę to lama. } & jama & & & & & \\
\hline & & & lama & & & & & \\
\hline \multirow{2}{*}{5.} & \multirow{2}{*}{$/ g /: / t /$} & \multirow[t]{2}{*}{ To nuty i gama, to na rzece tama. } & gama & & & & & \\
\hline & & & tama & & & & & \\
\hline
\end{tabular}

\begin{tabular}{|c|c|c|c|c|c|c|c|c|}
\hline Lp. & \multicolumn{3}{|c|}{ Sposób artykulacji } & 1 & 2 & 3 & 4 & Wynik \\
\hline \multirow{2}{*}{1.} & \multirow{2}{*}{ |ś/: /ćl } & \multirow{2}{*}{$\begin{array}{c}\text { To są drzewa w lesie, a to plaża } \\
\text { w lecie. }\end{array}$} & w lesie & & & & & \\
\hline & & & w lecie & & & & & \\
\hline \multirow{2}{*}{2.} & \multirow{2}{*}{$/ \mathrm{r} /: / / /$} & \multirow{2}{*}{$\begin{array}{c}\text { To jest od obrazu rama, to zwierzę } \\
\text { to lama. }\end{array}$} & rama & & & & & \\
\hline & & & lama & & & & & \\
\hline
\end{tabular}

\begin{tabular}{|c|c|c|c|c|c|c|c|c|}
\hline Lp. & \multicolumn{3}{|c|}{ Miejsce artykulacji } & 1 & 2 & 3 & 4 & Wynik \\
\hline \multirow{2}{*}{1.} & \multirow{2}{*}{ /s/ : /š/ } & \multirow[t]{2}{*}{ W sklepie stoi kasa, na talerzu leży kasza. } & kasa & & & & & \\
\hline & & & kasza & & & & & \\
\hline \multirow{2}{*}{2.} & \multirow{2}{*}{ |z/ : /ž/ } & \multirow[t]{2}{*}{ Zwierzę w paski to zebra, a tutaj są ludzkie żebra. } & zebra & & & & & \\
\hline & & & żebra & & & & & \\
\hline \multirow{2}{*}{3.} & \multirow{2}{*}{ /c/ : /čl } & \multirow[t]{2}{*}{ To niebieska tacka, a to ogrodowa taczka. } & tacka & & & & & \\
\hline & & & taczka & & & & & \\
\hline \multirow{2}{*}{4.} & \multirow{2}{*}{$/ \mathrm{d} /:$ /g/ } & \multirow[t]{2}{*}{ To jest wiejska dróżka, a to do jedzenia gruszka. } & dróżka & & & & & \\
\hline & & & gruszka & & & & & \\
\hline \multirow{2}{*}{5.} & \multirow{2}{*}{$/ \mathrm{t} /: / \mathrm{k} /$} & \multirow[t]{2}{*}{ To jest ogrodowa taczka, po podwórku chodzi kaczka. } & taczka & & & & & \\
\hline & & & kaczka & & & & & \\
\hline \multirow{2}{*}{6.} & \multirow{2}{*}{$/ \mathrm{p} /: / \mathrm{k} /$} & \multirow[t]{2}{*}{ Na poczcie jest paczka, po podwórku chodzi kaczka. } & paczka & & & & & \\
\hline & & & kaczka & & & & & \\
\hline \multirow{2}{*}{7.} & \multirow{2}{*}{$/ \mathrm{v} /: / \mathrm{z} /$} & \multirow[t]{2}{*}{ Pociąg ma wagony, a na polu są zagony. } & wagony & & & & & \\
\hline & & & zagony & & & & & \\
\hline \multirow{2}{*}{8.} & \multirow{2}{*}{$/ f /: / x /$} & \multirow[t]{2}{*}{ Do siedzenia służy fotel, ten budynek to jest hotel. } & fotel & & & & & \\
\hline & & & hotel & & & & & \\
\hline \multirow{2}{*}{9.} & \multirow{2}{*}{$/ \mathrm{u} /: / \mathrm{v} /$} & \multirow[t]{2}{*}{ To jest na balonie łata, a to miękka wata. } & tata & & & & & \\
\hline & & & wata & & & & & \\
\hline \multirow{2}{*}{10.} & \multirow{2}{*}{$/ \mathrm{b} /: / \mathrm{g} /$} & \multirow[t]{2}{*}{ To jest w klubie bar, to jest na zupę gar. } & bar & & & & & \\
\hline & & & gar & & & & & \\
\hline \multirow{2}{*}{11.} & \multirow{2}{*}{$/ \mathrm{m} /: / \mathrm{n} /$} & To jest pana muszka, a to dziecięca nóżka. & muszka & & & & & \\
\hline & & & nóżka & & & & & \\
\hline
\end{tabular}

\begin{tabular}{|c|c|c|c|c|c|c|c|c|}
\hline Lp. & \multicolumn{3}{|c|}{ Bezdźwięczne/dźwięczne } & 1 & 2 & 3 & 4 & Wynik \\
\hline \multirow{2}{*}{1.} & \multirow{2}{*}{$|s /:| z \mid$} & \multirow[t]{2}{*}{ Trawę kosi ostra kosa, mleko daje zwierzę koza. } & kosa & & & & & \\
\hline & & & koza & & & & & \\
\hline \multirow{2}{*}{2.} & \multirow{2}{*}{ /ś/ : /ź/ } & \multirow{2}{*}{$\begin{array}{c}\text { Te dziewczynki to dwie Basie, na gałązkach widać } \\
\text { bazie. }\end{array}$} & Basie & & & & & \\
\hline & & & bazie & & & & & \\
\hline \multirow{2}{*}{3.} & \multirow{2}{*}{ /Š/ : /Ž/ } & \multirow[t]{2}{*}{ Do noszenia służą nosze, do krojenia służą noże. } & nosze & & & & & \\
\hline & & & noże & & & & & \\
\hline \multirow{2}{*}{4.} & \multirow{2}{*}{ |ć/: /’́'/ } & \multirow[t]{2}{*}{ To jest bucik, ze snu budzi budzik. } & bucik & & & & & \\
\hline & & & budzik & & & & & \\
\hline
\end{tabular}




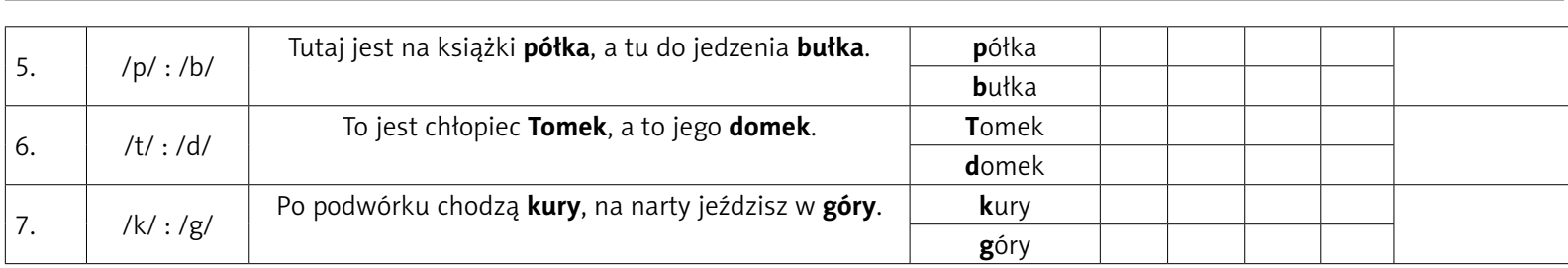

\begin{tabular}{|l|l|l}
\hline & Uwagi: \\
\hline
\end{tabular}

\begin{tabular}{|l|c|c|c|}
\hline \multirow{2}{*}{ Wiek } & \multicolumn{3}{|c|}{ Poziom słuchu fonemowego } \\
\cline { 2 - 4 } & wysoki & przeciętny & niski \\
\hline $3 ; 0-3 ; 11$ & $0-4$ błędy & $4-14$ błędów & $15-30$ błędów \\
\hline $4 ; 0-4 ; 11$ & $0-1$ błąd & $2-9$ błędów & 10-30 błędów \\
\hline $5 ; 0-5 ; 11$ & 0 błędów & $1-3$ błędy & błędów \\
\hline $6 ; 0-7 ; 6$ & 0 błędów & 1 błąd & $2-30$ błędów \\
\hline
\end{tabular}

półka : bułka - Tutaj jest na książki półka, a tu do jedzenia bułka), co znacznie ułatwiło dzieciom identyfikację usłyszanych nazw z oglądanym obrazkiem. Do narzędzia załączona jest karta zapisu poprawnych i niepoprawnych odpowiedzi, która umożliwia jednoznaczną interpretację i obliczanie wyników. Normalizacja testu pozwala określić miejsce badanego dziecka w grupie wiekowej.

Badania były wykonywane indywidualnie z każdym dzieckiem w wyciszonym pomieszczeniu. Przed badaniem właściwym prezentowano dzieciom paronimy wstępne i objaśniano, na czym polega sprawdzenie słuchu fonemowego. Osoby badające, zgodnie z instrukcją, wypowiadały sześć razy nazwy obrazków prezentujące daną parę wyrazów, np. bucik, budzik, bucik, bucik, budzik, budzik, i odnotowywały w karcie badania słuchu fonemowego prawidłowe bądź nieprawidłowe odpowiedzi uczniów. Dwa lub trzy popełnione błędy wskazywały na problemy $\mathrm{z}$ różnicowaniem danej pary fonemów opozycyjnych. Jeżeli podczas sześciu prób dziecko popełniło jeden błąd, badająca wypowiadała dodatkowo dwa razy nazwy obrazków (w sumie osiem). Kiedy w trakcie kolejnych dwóch prób dziecko nie popełniło więcej błędów, uznawano, że wcześniejsza błędna odpowiedź była kwestią przypadku.

\section{Wyniki}

W grupie badanej uczniowie łącznie popełnili 24 błędy. Dwanaścioro dzieci poprawnie różnicowało wszystkie opozycje. Pięcioro uczniów udzieliło od 1 do 2 błędnych odpowiedzi. Jeden uczeń pomylił się czterokrotnie, natomiast u dwójki 7-latków odnotowano więcej niż 5 błędów. W grupie kontrolnej 18 badanych dzieci prawidłowo różnicowało wszystkie opozycje fonologiczne. Jeden uczeń popełnił 2, a drugi 3 błędy w zakresie słuchowego różnicowania fonemów różniących się dwiema cechami dystynktywnymi i fonemów z opozycji sposobu artykulacji (paronimy - jama : rama, jama : lama, rama : lama). Obydwaj pierwszoklasiści nie realizowali głoski $r$ w wymowie, dokonując substytucji $(i, l)$.

W tabeli 2. przedstawiono statystykę błędów popełnionych $\mathrm{w}$ trakcie badań przez uczniów z obydwu badanych klas.

W opozycjach samogłoskowych J. Gruba zamieściła 10 paronimów. W grupie badawczej jeden 7-latek nie różnicował opozycji /u/:/o/. Reszta dzieci bezbłędnie różnicowała opozycje samogłoskowe. W przypadku opozycji fonemów różniących się dwiema cechami dystynktywnymi troje dzieci nieprawidłowo różnicowało fonemy /r/:/i/, a kolejna trójka popełniła błędy w różnicowaniu /n/:/d/. W grupie fonemów różniących się sposobem artykulacji znalazły się pary: /ś/:/ć/ oraz /r/:/l/. Ich słuchowe różnicowanie nie sprawiało 7-latkom większych trudności. Troje dzieci $(12,5 \%)$ miało problem $\mathrm{z}$ prawidłowym wskazaniem paronimów $\mathrm{z}$ fonemami /r/:/l/. Byli to uczniowie, którzy nie realizują głoski $r$ w wymowie, zamieniając ją na $l$. Dzieci z klasy integracyjnej popełniły 7 błędów podczas różnicowania opozycji fonemów z miejsca artykulacji. Trudności w różnicowaniu

Tabela 2. Liczba błędów odnotowanych w grupie badawczej i kontrolnej

Table 2. Number of errors recorded in the research and control group

\begin{tabular}{lcccc}
\hline \multirow{2}{*}{ Liczba błędów } & \multicolumn{2}{c}{ Grupa badawcza } & \multicolumn{2}{c}{ Grupa kontrolna } \\
\cline { 2 - 5 } & Liczba uczniów & Procent badanej klasy & Liczba uczniów & Procent badanej klasy \\
\hline $0-2$ & 5 & 62,5 & 1 & 50 \\
\hline $3-5$ & 1 & 12,5 & 1 & 50 \\
\hline Powyżej 5 & 2 & 25 & 0 & 0 \\
\hline Ogółem & 8 & 100 & 2 & 100 \\
\hline
\end{tabular}


Tabela 3. Błędy w różnicowaniu opozycji fonologicznych w grupie badawczej

Table 3. Errors in the differentiation of phonological oppositions in the research group

\begin{tabular}{lccc}
\hline \multirow{2}{*}{ Lp. } & Opozycja & \multicolumn{2}{c}{ Błędne odpowiedzi } \\
\cline { 3 - 4 } & Liczba & Procent \\
\hline 1. & $/ \mathrm{u} /: / \mathrm{o} /$ & 1 & 4,16 \\
\hline 2. & $/ \mathrm{n} /: / \mathrm{d} /$ & 3 & 12,5 \\
\hline 3. & $/ \mathrm{r} /: / \mathrm{l} /$ & 3 & 12,5 \\
\hline 4. & $/ \mathrm{s} /: / \mathrm{s} /$ & 5 & 20,83 \\
\hline 5. & $/ \mathrm{s} /: / \check{z} /$ & 2 & 8,33 \\
\hline 6. & $/ \mathrm{c} /: / \check{c} /$ & 2 & 8,33 \\
\hline 7. & $/ \mathrm{p} /: / \mathrm{b} /$ & 5 & 20,83 \\
\hline 8. & $/ \mathrm{k} /: / \mathrm{g} /$ & 3 & 12,5 \\
\hline Ogółem & & 24 & 100,00 \\
\hline
\end{tabular}

/s/:/š/ oraz /c/:/č/ miały dzieci z wadami wymowy oraz chłopcy $\mathrm{z}$ afazją motoryczną. Dziesięć błędnych odpowiedzi ( $5 \mathrm{w}$ paronimach - półka : bułka, 3 - kury : góry i 2 - Basie : bazie) odnotowano podczas różnicowania fonemów z fonologicznej kategorii dźwięczności.

Analiza danych potwierdziła wysoki poziom słuchu fonemowego u 12 dzieci, co stanowi $60 \%$ badanej klasy integracyjnej. Natomiast u 8 uczniów (40\%) zdiagnozowano niski poziom słuchu fonemowego. W grupie kontrolnej 18 badanych dzieci prawidłowo różnicowało wszystkie opozycje fonologiczne, a zatem $90 \%$ tej klasy osiągnęło wysoki poziom słuchu fonemowego. Dwóch 7-latków z grupy kontrolnej, którzy popełnili 2 i 3 błędy, uplasowało się na niskim poziomie słuchu fonemowego.

\section{Dyskusja}

Do tej pory nie jest znany mechanizm przebiegu czynności percepcyjnych. Badacze poszukują odpowiedzi na pytanie, czy identyfikacja sygnałów językowych przez dziecko opiera się na wrodzonej zdolności do rozpoznawania jednostek sensorycznych o pewnym rodzaju cech pozwalających odróżniać je od siebie (co umożliwiałoby uczenie się odróżniania konkretnych sylab, a w nich głosek danego języka), a następnie dopasowania własnych artykulacji do tych wzorów [20]. Czy też dziecko, poznając funkcje pewnych sekwencji dźwięków oraz ich elementy składowe i cechy, dzięki nabytemu doświadczeniu językowemu (słuchaniu i generowaniu słów) tworzy sobie samo umysłowe modele jednostek sensoryczno-motorycznych, zawierających zbiory cech ważnych jednostek znaczących, umożliwiających mu odróżnienie i rozpoznawanie [20]. Ośmioro dzieci z klasy integracyjnej, u których w podsumowaniu wyników badań stwierdzono niski poziom słuchu fonemowego, miało również problemy $\mathrm{z}$ rozpoznawaniem liter, analizą i syntezą głoskową, z czytaniem metodą analityczno-syntetyczną oraz pisaniem ze słuchu, $\mathrm{z}$ pamięci i przepisywaniem $\mathrm{z}$ tablicy. $\mathrm{W}$ trakcie czytania synteze wyrazu zaburzał wokaliczny element głoski (w postaci samogłoski $y$, np. $d y-o-m y$ ), którego uczniowie nie potrafili pominąć jako dźwięku nieistotnego. Dzieci wkładały cała energię w wydzielanie poszczególnych głosek i często, na końcu wyrazu, zapominały, co czytały na początku. Dwóch uczniów stosowało strategię czytania przez domyślanie się, co całkowicie zaburzało rozumienie nawet zdań prostych. P. Łobacz stwierdza, że dopiero podczas nauki czytania uaktywnia się wiedza metajęzykowa dziecka, a świadomość fonologiczna (wiedza na temat dźwiękowej struktury języka, tzn. zdawanie sobie sprawy z tego, że wyrazy złożone są z sylab i fonemów, mogą się rymować, zaczynać i kończyć taką samą głoską) jest katalizatorem nabywania umiejętności czytania i pisania [21]. Z drugiej strony - nauka czytania rozwija świadomość fonologiczną, co potwierdzają przytaczane przez P. Łobacz badania dzieci japońskich uczących się pisma w swym rodzimym języku. Okazało się, że świadomość fonemowa rozwija się u tych dzieci dopiero w wieku 10-12 lat. Natomiast ci japońscy uczniowie, którzy dodatkowo uczyli się jakiegoś języka europejskiego, szybciej osiągali świadomość fonologiczną [22]. Umiejętność czytania wymaga, aby prawidłowo przebiegały procesy analogiczne do tych, jakie zachodzą w procesie nabywania mowy [21]. Różnice między

Tabela 4. Liczba odpowiedzi poprawnych i błędnych w poszczególnych parach opozycyjnych w grupach badawczej i kontrolnej Table 4. The number of correct and incorrect answers in individual opposition pairs in the research and control groups

\begin{tabular}{lcccccccc}
\hline & \multicolumn{3}{c}{ Grupa badawcza } & \multicolumn{3}{c}{ Grupa kontrolna } \\
\cline { 2 - 9 } Opozycja fonologiczna & \multicolumn{2}{c}{$\begin{array}{c}\text { Odpowiedzi } \\
\text { poprawne }\end{array}$} & $\begin{array}{c}\text { Odpowiedzi } \\
\text { błędne }\end{array}$ & \multicolumn{2}{c}{$\begin{array}{c}\text { Odpowiedzi } \\
\text { poprawne }\end{array}$} & $\begin{array}{c}\text { Odpowiedzi } \\
\text { błędne }\end{array}$ \\
\cline { 2 - 9 } & Liczba & Procent & Liczba & Procent & Liczba & Procent & Liczba & Procent \\
\hline Opozycje samogłoskowe & 19 & 95 & 1 & 5 & 20 & 100 & 0 & 0 \\
\hline Dwie cechy dystynktywne & 17 & 85 & 3 & 15 & 18 & 90 & 2 & 10 \\
\hline Sposób artykulacji & 17 & 85 & 3 & 15 & 17 & 85 & 3 & 15 \\
\hline Miejsce artykulacji & 13 & 65 & 7 & 35 & 20 & 100 & 0 & 0 \\
\hline Dźwięczność - bezdźwięczność & 10 & 50 & 10 & 50 & 20 & 100 & 0 \\
\hline
\end{tabular}


dobrze i słabo czytającymi dziećmi są powiązane $\mathrm{z}$ ich postępami w nabywaniu języka [22]. Dziecko aktywne językowo, z prawidłowo rozwiniętą artykulacją ma wystarczające sprawności fonologiczne do rozpoczęcia nauki czytania i pisania. Jeśli zasadnicza dla rozwoju kompetencji komunikacyjnej czynność słuchowego różnicowania głosek jest zaburzona, jej następstwem są trudności w zakresie wyższych umiejętności związanych z nabywaniem języka. U trzech chłopców $\mathrm{z}$ afazją motoryczną zaobserwowano trudności z: utrzymaniem słów w pamięci, rozumieniem zdań-rymowanek, skupieniem uwagi słuchowej na fonicznym ciągu mowy i odwoływaniem się do pamięci przechowującej znane wyrazy. Natomiast w przypadku dzieci ze zdiagnozowaną dyslalią - wady wymowy i zaburzenia słuchu fonemowego miały odzwierciedlenie w pisowni. Podczas przeprowadzanych badań 7-latki dopiero zaczynały naukę pisania, niemniej już wówczas dostrzeżono w ich zeszytach zaburzenia kategorii dźwięczności, miękkości, substytucje, a czasem dopisywanie samogłosek świadczące o cichym dyktowaniu sobie zgodnie $\mathrm{z}$ analizą głoskową (np. w wyrazie pani zapis: pyany). Jeśli uczeń nie realizował w mowie głosek dźwięcznych i nie różnicował ich w percepcji słuchowej, to również $\mathrm{w}$ jego pisowni pojawiała się zamiana głosek: $b$ na $p, d$ na $t$ czy $\check{z}$ na $\check{s}$. Podobne wnioski odnotowała w badaniach J. Gruba, mianowicie nieprawidłowe słuchowe różnicowanie fonemów wpływa na nieprawidłową artykulację u dzieci 6- i 7-letnich [19].

W grupie kontrolnej uczniowie nie mieli trudności w pisaniu, zapamiętywaniu i prawidłowym rozpoznawaniu liter, syntezie głosek i czytaniu prostych wyrazów czy zdań. Jest wysoce prawdopodobne, że chłopcy, którzy podczas badania popełnili błędy w różnicowaniu fonemów, po intensywnych i systematycznych ćwiczeniach logopedycznych będą potrafili rozróżniać słuchowo i prawidłowo realizować głoskę $r$. W ich przypadku wskazana jest weryfikacja badań po roku nauki w szkole i po terapii logopedycznej.

\section{Wnioski}

Prawidłowo ukształtowany słuch fonemowy ma zasadnicze znaczenie dla rozwoju kompetencji językowych (mówienia, czytania i pisania) 7-latków. Zaprezentowane badania stanowią analizę pilotażową, odnoszącą się tylko do tej jednej badanej klasy integracyjnej. Na podstawie uzyskanych danych sformułowano następujące wnioski:

1. Przeprowadzone badania wykazały, że $40 \%$ uczniów I klasy integracyjnej stanowiącej grupę badaną ma utrudniony start edukacyjny $z$ powodu zaburzeń słuchu fonemowego i innych problemów w rozwoju językowym.

2. W omawianej klasie I zaburzenia słuchu fonemowego skutkują trudnościami w rozwoju mowy oraz nauce czytania i pisania.

3. Zaburzenia słuchu fonemowego są jedną z przyczyn wad wymowy oraz trudności w analizie i syntezie głoskowej wyrazów. Fonemy, których badani uczniowie nie różnicowali słuchowo, często nie pojawiały się również w zapisie.

4. Analiza danych przyczyniła się do wprowadzenia w szkole programu terapeutycznego dla dzieci z zaburzeniami słuchu fonemowego.

5. Wyniki wskazują na potrzebę kontynuacji badań przesiewowych słuchu fonemowego w klasach zerowych i pierwszych.

\section{Piśmiennictwo}

1. Kaczmarek BLJ. Aleksander Romanowicz Łurija: jeden $z$ wielkich romantyków. Przegląd Psychologiczny, 2001; 44(1): 105-117.

2. Kania J. Szkice logopedyczne. Warszawa: WSiP; 1982.

3. Styczek I. Badanie i kształtowanie słuchu fonematycznego (komentarz i tablice). Warszawa: WSiP; 1982.

4. Rocławski B. Słuch fonemowy i fonetyczny. Teoria i praktyka. Gdańsk: Glottispol; 2010.

5. Kurkowski ZM. Słuch a mowa w aspekcie rozwojowym w normie i patologii. Kosmos, 1998; 47(3): 289-96.

6. Domagała A, Mirecka U. Słuch fonemowy a uwarunkowania komunikacji językowej. W: Język. Interakcja. Zaburzenia mowy. Metodologia badań. Woźniak T, Domagała A (red.). Lublin: Wydawnictwo UMCS; 2007.

7. Domagała A, Mirecka U. Słuch fonemowy. W kierunku kompetencji fonologicznej. Logopedia, 2002; 30: 7-26.

8. Szeląg E, Szymaszek A. Test do badania słuchu fonematycznego u dzieci i dorosłych. Gdańsk: GWP; 2006.

9. Cieszyńska-Rożek J, Korendo M. Jak neurobiologia wyjaśnia trudności w nauce czytania i pisania. W: Zaburzenia komunikacji pisemnej. Domagała A, Mirecka U (red.). Gdańsk: Grupa Wydawnicza Harmonia; 2017.

10. Domagała A, Mirecka U. Słuch fonemowy. Odkrywanie elementarnych jednostek systemu językowego. Logopedia, 2001; 29: 68.
11. Liberman IY, Shankweiler D. Phonology and the problems of learning to read and write. Remedial and Special Education, 1985; 6(6): 8-17.

12. Krasowicz-Kupis G. Rozwój świadomości językowej dziecka. Teoria i praktyka. Lublin: Wydawnictwo UMCS, 2004.

13. Krasowicz-Kupis G. Rozwój metajęzykowy a osiągnięcia w czytaniu u dzieci 6-9-letnich. Lublin: Wydawnictwo UMCS; 1999.

14. Galińska-Grzelewska D. Poziom i dynamika rozwoju percepcji w zakresie analizy fonemowej słów u dzieci w wieku 6 i 7 lat. W: Zaburzenia w komunikacji językowej w czytaniu i pisaniu. Maciejewska A (red.). Siedlce: Wydawnictwo Akademii Podlaskiej; 2007.

15. Rocławski B. Podstawy wiedzy o języku polskim dla glottodydaktyków, pedagogów, psychologów i logopedów. Gdańsk: Glottispol; 2001.

16. Demel G. Minimum logopedyczne nauczyciela przedszkola. Warszawa: WSiP; 2008.

17. Chrzanowska A, Szoplik K. Zabawy i ćwiczenia logopedyczne. Poradnik dla logopedów, nauczycieli i rodziców, Białystok: Wydawnictwo Akademickie; 2006.

18. Gruba J. Test do badania słuchu fonemowego. Gliwice: Komlogo; 2012.

19. Gruba J. Ocena słuchu fonemowego u dzieci w wieku przedszkolnym. Katowice: Wydawnictwo Uniwersytetu Śląskiego; 2012. 
20. Krakowiak K. Dar języka. Podręcznik metodyki wychowania językowego dzieci i młodzieży z uszkodzeniami narządu słuchu. Lublin: Wydawnictwo KUL; 2012.

21. Cieszyńska-Rożek J. Metoda Krakowska wobec zaburzeń rozwoju dzieci. Z perspektywy fenomenologii, neurobiologii i językoznawstwa. Kraków: Wydawnictwo Metody Krakowskiej; 2013.
22. Łobacz P. Nabywanie systemu fonologicznego a świadomość fonologiczna dzieci. W: Rozwój poznawczy i rozwój językowy dzieci z trudnościami w komunikacji werbalnej. Diagnozowanie i postępowanie usprawniające. Mierzejewska H, Przybysz-Piwko M (red.). Warszawa: DiG, 1997. 